\title{
Grand Juries and Cases of Police Use of Deadly Force: Are Prosecutors Opening a Closed Door?
}

\section{Joseph P. Conti}

\begin{abstract}
In recent years, considerable national attention has been focused upon cases in which police officers used deadly force that resulted in the death of private citizens. The officers often contended that the use of deadly force was justified under the circumstances. Prosecutors then presented these cases to grand juries to determine whether criminal prosecutions were warranted. Some prosecutors have elected to provide full grand jury reviews that include the presentation of exculpatory evidence or at least evidence favorable to the police. Although prosecutors have no constitutional obligation to provide such reviews, those who elect to provide full grand jury reviews to police potentially open the door to the imposition of legal and ethical obligations to provide such reviews to private citizens who have used deadly force that resulted in the death of another person and who, like the police officers, contend that the use of deadly force was justified under the circumstances. ${ }^{1}$
\end{abstract}

\section{Keywords}

grand jury, deadly force, prosecution, policing

\footnotetext{
${ }^{1}$ The information contained within this article does not provide and should not be relied upon as legal advice or opinion. This article should not be used or relied upon to address any particular facts or circumstances before a lawyer has been consulted. The information and opinions set forth within this article may or may not reflect the views of Edinboro University.
}

\footnotetext{
' Department of Criminal Justice, Anthropology, and Forensic Studies, Edinboro University, Edinboro, PA, USA

Corresponding Author:

Joseph P. Conti, Department of Criminal Justice, Anthropology, and Forensic Studies, Edinboro University, Edinboro, PA, 16412, USA, Email: jconti@edinboro.edu
}

The authors wish to extend their appreciation to the blind reviewers of the original manuscript for their helpful comments in preparing the final version of the manuscript. 


\section{Introduction}

At the outset, clarification of certain terminology should be undertaken. Throughout this article, references will be made to "police officer cases," "private citizen cases," and "full grand jury reviews." As used within this article, the term "police officer cases" refers to those instances in which a police officer during the course of performing his or her law enforcement duties used deadly force that resulted in the death of a person. Further, the police officer has claimed that the use of deadly force was justifiable under the circumstances of the case. The term "private citizen cases" refers to those instances in which a private citizen used deadly force that resulted in the death of a person. Like the police officer, the private citizen has claimed that the use of deadly force was justifiable under the circumstances of the case. Both types of cases entail the potential misuse of deadly force that resulted in the death of a person and corresponding claims by the actor that the use of deadly force was justifiable under the circumstances. It is imperative to keep in mind when reviewing this article that "private citizen cases" do not include any other forms of cases in which private citizens may be facing criminal liability. Finally, as used within this article, the term "full grand jury review" involves the presentation by prosecutors of all relevant evidence pertaining to the use of deadly force by a suspect, including but not limited to evidence submitted by the suspect for review and consideration by the grand jury, evidence that is exculpatory in nature, and/or evidence that is favorable to the suspect even if not exculpatory in nature.

In recent years, considerable national public and media attention has been focused upon police officer cases. In response to community demands for reviews in those cases, some prosecutors through the lawful exercise of their discretion have resorted to presenting the cases to grand juries to determine whether criminal prosecutions of the police officers are warranted. The traditional role of grand juries has not been to review evidence that is either exculpatory in nature or at least favorable to the suspect. Indeed, the Supreme Court of the United States (hereinafter referred to as "The Court") to date has not required prosecutors to present such evidence to grand juries. Yet, the public has become keenly aware of the fact that some prosecutors have elected to present exculpatory evidence to grand juries for consideration in police officer cases.

Over the years, considerable scholarly attention has been given to the use of grand jury proceedings and the disclosure of exculpatory evidence in grand jury proceedings. Some have called for the complete elimination of any opportunity to have cases involving police officers presented to grand juries for review. ${ }^{2}$ For reasons largely different from those set forth in this article, it has also been argued that a full grand jury process should be extended to all potential criminal cases against private citizens, or at least those involving felonies, as well as to a wide range of cases involving potential criminal activity by police officers. ${ }^{3}$ An argument has also been proffered for the amendment of Rule 6 of the Federal Rules of Criminal Procedure to require the disclosure of exculpatory evidence in felony federal grand jury proceedings. ${ }^{4}$ Finally, an argument

\footnotetext{
${ }^{2}$ See Kate Levine, How We Prosecute the Police, 104 Geo. L. J. 745, 749 footnote 15 (2016).

3 Id. , at 745-776.

${ }^{4}$ See Suzanne Roe Neely, Preserving Justice and Preventing Prejudice: Requiring Disclosure of Substantial Exculpatory Evidence to the Grand Jury, 39 Am. Crim. L. Rev. 171, 196 (2002).
} 
has been advanced that in all state grand jury proceedings, prosecutors should be required to present all substantial and admissible exculpatory evidence. ${ }^{5}$

The purpose of this article is not to advocate the wholesale abolition of grand jury proceedings. As well, the purpose of this article is not to advocate the use of full grand jury reviews in all felony and misdemeanor cases at the state level. Viable constitutional arguments for such an approach are not likely to exist. Also, the nationwide use of full grand jury reviews in millions of cases each year would be quite costly and unmanageable. Moreover, this article is not intended to argue that the presentation of exculpatory evidence in police officer cases is, in and of itself, inappropriate.

This article does, however, focus upon the constitutional and ethical implications of a top prosecutor's decision to use full grand jury reviews to address the potential criminal liability of police officers in police officer cases, yet to deny full grand jury reviews to private citizens in private citizen cases. Police officer cases have recently received substantial national attention, and the manner in which they are handled by prosecutors has serious constitutional and ethical implications, as well as serious implications for the level of confidence in our criminal justice system that the public maintains.

As noted previously, the traditional role of grand juries has not been to review evidence that is either exculpatory in nature or at least favorable to a suspect. The Court has determined as a general rule that prosecutors are not required to present such evidence to grand juries regardless of the identity or circumstances of the defendant. However, although no federal constitutional provision requires them to do so, some prosecutors have elected to employ full grand jury reviews in police officer cases by presenting, along with other relevant evidence, evidence that is exculpatory in nature or at least favorable to the police officers. That approach to police officer cases raises an important legal and ethical question: Once prosecutors have themselves elected to transform the grand jury process from its traditional role to a more expanded role by providing full grand jury reviews in police officer cases, what legally and ethically viable basis exists to allow those same prosecutors to deny full grand jury reviews in private citizen cases?

This article examines the realistic prospect that prosecutors who provide full grand jury reviews in police officer cases open the door to the imposition of legal and ethical obligations to provide full grand jury reviews in private citizen cases in which private citizens, like the police officers, contend that their use of deadly force was justified under the circumstances. Essentially, there are significant legal and ethical reasons to conclude that once prosecutors resort to the use of full grand jury reviews in police officer cases, they may have created a corresponding obligation to provide the same reviews in private citizen cases. It is worthy of note that there are no case decisions that directly address this particular legal and ethical issue. Nevertheless, to examine the legal and ethical implications of providing full grand jury reviews in police officer cases, an effort has been undertaken to extrapolate from existing case decisions.

\footnotetext{
${ }^{5}$ See R. Michael Cassidy, Toward a More Independent Grand Jury: Recasting and Enforcing the Prosecutor's Duty to Disclose Exculpatory Evidence, 13 Geo. J. Legal Ethics 361, 403 (1999-2000).
} 


\section{The Transformation of Grand Jury Proceedings Analysis}

\section{A. Traditional Grand Juries and the Disclosure of Exculpatory Evidence}

Within the United States, either of two types of grand jury is employed. One form of grand jury conducts investigations and ultimately decides whether to recommend to the prosecutor that a particular person be charged with criminal offenses. The recommendation to the prosecutor is set forth in a legal document commonly known as a presentment. ${ }^{6} \mathrm{~A}$ second form of grand jury examines testimony and evidence ultimately to decide whether probable cause for a prosecution exists. If it determines that probable cause does exist, the grand jury issues an indictment setting forth the charges. If it determines that probable cause does not exist, the grand jury issues a no bill. ${ }^{7}$ Prosecutors can use either form of grand jury to address police officer cases and private citizen cases. In addition, in either form of grand jury proceeding, the traditional role of the prosecutor is to serve as the government representative and is the only person involved in conducting the proceedings. Defense counsel is not present during the proceedings, and the suspect is not permitted to be present unless he or she has received a subpoena to appear and testify. The prosecutor is permitted to select the evidence that will be received and reviewed by the grand jury. In essence, the prosecutor controls the grand jury's access to information. ${ }^{8}$ Finally, grand jury proceedings are not open to the public and are conducted in secret. ${ }^{9}$

The Court has not, through the Fourteenth Amendment Due Process provision, incorporated the Fifth Amendment Grand Jury provision and made it applicable to the states. ${ }^{10}$ Therefore, the states are free to implement a grand jury system or to proceed by criminal information. ${ }^{11}$ In 49 states plus the District of Columbia, criminal justice systems are maintained that either require or at least permit the use of grand juries by prosecutors to obtain indictments. ${ }^{12}$ Specifically, 23 of the 49 states and the District of Columbia require grand jury indictments for most or all felony offenses, ${ }^{13}$ and 25 of the 49 states authorize the option of seeking grand jury indictments for most felonies. ${ }^{14}$ Finally, Pennsylvania, the last of the 49 states, allows prosecutors the option of pursuing

\footnotetext{
${ }^{6}$ See Larry J. Siegel and John L. Worrall, Essentials of Criminal Justice, 187 (Cengage, 10th Edition, 2015).

${ }^{7}$ Id. See also Ali Lombardo, The Grand Jury and Exculpatory Evidence: Should the Prosecutor Be Required to Disclose Exculpatory Evidence to the Grand Jury, 48 Clev. St. L. Rev. 829, 835 (2000).

${ }^{8}$ See Neely, supra, at 181.

9 See David W. Neubauer and Henry F. Fradella, America's Courts and the Criminal Justice System, 280 (Cengage, 12th Edition, 2015).

${ }^{10}$ See William J. Rich, Modern Constitutional Law, 164 (West, Vol. 2, Third Edition, 2011); see also McDonald v. City of Illinois, 561 U.S. 742, 765 (2010).

${ }^{11}$ See Michigan v. Long, 463 U.S. 1032, 1040-1041 (1983).

${ }^{12}$ See Neubauer and Fradella, supra, at 279 (Cengage, 12th Edition, 2015).

${ }^{13}$ Id. (The 23 states that require grand jury indictments are Alabama, Alaska, Delaware, Florida, Kentucky, Louisiana, Maine, Massachusetts, Minnesota, Mississippi, Missouri, New Hampshire, New Jersey, New York, North Carolina, North Dakota, Ohio, Rhode Island, South Carolina, Tennessee, Texas, Virginia, and West Virginia.)

${ }^{14}$ Id. (The 25 states that have a grand jury option are Arizona, Arkansas, California, Colorado, Georgia, Hawaii, Idaho, Illinois, Indiana, lowa, Kansas, Maryland, Michigan, Montana, Nebraska, Nevada, New Mexico, Oklahoma, Oregon, South Dakota, Utah, Vermont, Washington, Wisconsin, and Wyoming.)
} 
grand jury indictments when witness intimidation is an issue. ${ }^{15}$ Connecticut is the only state in the country that has abolished the use of grand jury indictments. ${ }^{16}$ In 45 states, the top prosecutor at the county level who is authorized to use grand jury proceedings is an elected district attorney or a county prosecutor. ${ }^{17}$

On the grounds that it has a limited supervisory role in federal court proceedings, The Court in United States $v$. Williams ${ }^{18}$ declined to impose a constitutional requirement for federal prosecutors to disclose exculpatory evidence in grand jury proceedings. ${ }^{19}$ For a better understanding of the importance and relevance of The Court's decision in United States $v$. Williams, a brief review of the legal history leading up that case is in order. In 1987, The United States Court of Appeals for the Tenth Circuit addressed the case of United States v. Page. ${ }^{20}$ The Circuit Court reviewed a claim by the defendant that his conviction should be set aside on the basis that the prosecutor failed to present exculpatory evidence to the grand jury that issued the indictment. ${ }^{21}$ The Circuit Court reviewed the legal history surrounding the issue of whether prosecutors were required under the Constitution to present exculpatory evidence to a grand jury. Specifically, the Circuit Court noted that two views existed within the United States Courts of Appeals.

The view of some courts was that prosecutors had no constitutional obligation to present exculpatory evidence to a grand jury. ${ }^{22}$ That view was based upon the understanding that the grand jury has traditionally been required to determine whether probable cause exists to support a prosecution, not to determine the guilt or innocence of the potential defendant. ${ }^{23}$ Concerns about the creation of a "mini-trial" quality in grand jury proceedings were expressed by some courts well before United States $v$. Page when they addressed the question of whether an obligation to present exculpatory evidence should be imposed. ${ }^{24}$

A second view, expressed by other courts, was that prosecutors did have a constitutional obligation to present exculpatory evidence to a grand jury if that evidence clearly negated the defendant's guilt. ${ }^{25}$ The second view stressed the importance of allowing a grand jury to hear all

\footnotetext{
15 Pennsylvania Rule of Criminal Procedure 556, Indicting Grand Jury (adopted June 21, 2012; amended September 8, 2015).

${ }^{16}$ See Neubauer and Fradella, supra, at 279.

${ }^{17}$ See Eric S. Fish, Prosecutorial Constitutionalism, 90 S. Cal. L. Rev. 237, 280 (2017).

${ }^{18}$ See United States v. Williams, 504 U.S. 36 (1992).

${ }^{19}$ See United States v. Williams, 504 U.S. at 45, 55 (1992); see also Susan W. Brenner and Lori E. Shaw, Federal Grand Jury: A Guide to Law and Practice, 315-317 (Thomson-West, Vol. 1, Second Edition, 2006); see also Susan W. Brenner and Lori E. Shaw, Federal Grand Jury: A Guide to Law and Practice, 241 (Thomson-West, Vol. 2, Second Edition, 2006).

${ }^{20}$ See United States v. Page, 808 F.2d 723 (10th Cir. 1987).

21 Id., at 727.

22 ld. (The Circuit Court referenced by example case decisions from the Courts of Appeals for the Sixth, Eighth, and Ninth Circuits.)

23 Id.

${ }^{24}$ See United States v. Ciambrone, 601 F.2d 622 (2nd Cir. 1979).

25 See United States v. Page at 727-728 (the Circuit Court referenced by example, case decisions from the Courts of Appeals for the Second and Seventh Circuits, including the decision in United States v. Ciambrone, supra).
} 
relevant evidence before it decided whether to issue an indictment. ${ }^{26}$ The Circuit Court in United States $v$. Page adopted the second view but denied the defendant's request to dismiss the indictment, reasoning that the evidence the defendant sought to present was not clearly exculpatory in nature. ${ }^{27}$

It comes as no surprise then that when the United States Court of Appeals for the Tenth Circuit was presented with first level of appeal in the case of United States v. Williams, ${ }^{28}$ the Circuit Court once again declared that prosecutors have a constitutional obligation to present substantial exculpatory evidence to a grand jury. ${ }^{29}$ The Circuit Court ultimately determined that the prosecutor had failed to satisfy that obligation and affirmed the trial court's dismissal of the indictment. ${ }^{30}$

On appeal from the Circuit Court, in United States v. Williams, ${ }^{31}$ The Court addressed a rather straightforward issue. As stated by The Court:

The question presented in this case is whether the district court may dismiss an otherwise valid indictment because the Government failed to disclose to the grand jury "substantial exculpatory evidence" in its possession. ${ }^{32}$

On the grounds that it has a limited supervisory role in federal court proceedings, The Court declined to impose a constitutional requirement for federal prosecutors to disclose exculpatory evidence in grand jury proceedings. ${ }^{33}$ In arriving at its decision, The Court at considerable length reviewed the historical legal underpinnings of the grand jury process. ${ }^{34}$ Although The Court did not make express reference to concerns about the creation of "mini-trials" within the context of grand jury proceedings, it nevertheless addressed the subject. As to that matter, The Court emphasized that the traditional purpose of the grand jury has not been to determine guilt or innocence, as would be done during a trial. ${ }^{35}$

In describing the traditional role of grand juries, The Court stated:

.. requiring the prosecutor to present exculpatory evidence as well as inculpatory evidence would alter the grand jury's historical role, transforming it from an accusatory to an adjudicatory body. ${ }^{36}$

It is axiomatic that the grand jury sits not to determine guilt or innocence, but to assess whether there is adequate basis for bringing a criminal charge (citation omitted). That has always been so; and to make the assessment, it has always been thought sufficient to hear only the prosecutor's side. ${ }^{37}$

$26 / d$.

27 Id., at 728.

${ }^{28}$ See United States v. Williams, 899 F.2d 898 (10th Cir. 1990).

${ }^{29}$ Id., at 900 .

${ }^{30}$ Id. , at 903-904.

${ }^{31}$ See United States v. Williams, 504 U.S. 36 (1992).

32 ld., at 37-38.

${ }^{33}$ Id., at 45,55; see also Brenner and Shaw, supra, at 315-317 (Thomson-West, Vol. 1, 2nd Edition, 2006); see also Brenner and Shaw, supra, at 241 (Thomson-West, Vol. 2, Second Edition, 2006).

${ }^{34}$ See United States v. Williams, 504 U.S. 47-51 (1992).

35 Id. , at 51 .

${ }^{36} \mathrm{Id}$.

${ }^{37} / d$. 
Imposing upon the prosecutor a legal obligation to present exculpatory evidence in his possession would be incompatible with this system. ${ }^{38}$

\section{B. Breaking With Tradition}

Although The Court in United States $v$. Williams declared as a general rule that prosecutors are not required under the U.S. Constitution to present exculpatory evidence to grand juries, The Court did not foreclose the opportunity to put exculpatory evidence requirements in place. As one example, on the federal level the Department of Justice has instituted a nonbinding internal policy that requires prosecutors to disclose to the grand jury substantial exculpatory evidence known to the prosecutor if that evidence negates the guilt of the subject of the investigation, regardless of the identity or occupation of the subject of the investigation. ${ }^{39}$ Because this is only an internal operating policy, it is subject to later amendment or elimination by the Department of Justice.

As another example, states are free to provide under their individual constitutions, statutes, and rules of procedure greater legal protections to defendants and suspects than are required under the U.S. Constitution. ${ }^{40}$ As one greater legal protection, states are free to require, and some states have required prosecutors to present, exculpatory evidence in grand jury proceedings. ${ }^{41}$ Of the 49 states that maintain criminal justice systems that include indicting grand juries, approximately one-third require the presentation of exculpatory evidence to grand juries. ${ }^{42}$ Therefore, the majority of the states that utilize indicting grand juries grant the prosecutor the discretion to decide whether exculpatory evidence will be presented during grand jury proceedings. By way of example, the states of Missouri (Brown case) and Ohio (Rice case), discussed later in greater detail, are included within the majority of states that grant discretion to prosecutors as to whether to present exculpatory evidence to grand juries.

In two prominent police officer cases, the prosecutors in the exercise of their discretion broke with tradition and provided full grand jury reviews to the police officers. Specifically, grand juries were empaneled to receive and review volumes of evidence, some of which included evidence favorable to the police officers, for the purpose of aiding the prosecutors in determining whether criminal charges were warranted against the officers. One case was based upon the fatal shooting of Michael Brown in Ferguson, Missouri, on August 9, 2014, by Officer Darren Wilson, who was on duty at the time and observed Michael Brown walking on a street following a reported convenience store episode. To determine whether a prosecution against Officer Wilson was warranted, the prosecution provided a full grand jury review of the case. There are now 19 volumes of transcribed testimony in existence as a result of the grand jury investigation. As part of the grand jury proceedings, testimony in support of Officer Wilson's claim of justifiable use of

\footnotetext{
${ }^{38} I d$, at 52.

${ }^{39}$ See Neely, supra, at 173; see also Brett Eaton, Relieving the Tension: New Mexico's Departure From the Federal Position That There Is No Requirement to Present Exculpatory Evidence to the Grand Jury, 41 N.M. L. Rev. 467, 498 (2011).

40 See Michigan v. Long, 463 U.S. 1040-1041.

${ }^{41}$ See State v. Hogan, 144 N.J. 216, 232-234 (1996); see also, Lombardo, supra, at 842-857.

42 See State v. Hogan, 144 N.J. 216, 233 (1996); see also Lombardo, supra, at 842-857; see also Cassidy, supra, at 382-392. (The states of Alaska, Arizona, California, Hawaii, Massachusetts, Minnesota, Montana, Nevada, New Jersey, North Dakota, Oregon, and Utah require the presentation of exculpatory evidence to grand juries. The same is required within the District of Columbia. New York, New Mexico, and Georgia provide an opportunity for the potential defendant to appear and present evidence.)
} 
deadly force was taken directly from Officer Wilson. In addition, the grand jury received the testimony of more than 50 witnesses $^{43}$ and received expert reports in the nature of crime laboratory firearm evidence, as well as drug test results, medical records, and a toxicology report for Officer Wilson. ${ }^{44}$ In the end, the grand jury declined to issue an indictment against Officer Wilson and instead issued a no bill of indictment. ${ }^{45}$

The second case was based upon the fatal shooting of Tamir Rice in Cleveland, Ohio, on November 22, 2014. Tamir Rice was fatally shot by Officer Timothy Loehmann when Officer Loehmann was responding to a call for law enforcement intervention along with his partner, Officer Frank Garmback. As was the case in Ferguson, Missouri, the prosecution provided a full grand jury review of the case to determine whether criminal charges against the officers were warranted. Both officers were permitted to submit written statements in support of the use of deadly force by Officer Loehmann. However, both officers chose not to testify, and therefore, neither officer was subjected to cross-examination by the prosecution. ${ }^{46}$ Experts retained by the prosecution prepared reports that were submitted to the grand jury. Those experts opined that Officer Loehmann acted reasonably under the circumstances. ${ }^{47}$ It is noteworthy that the Cuyahoga County Prosecutor's Office had previously enacted an office policy that a grand jury was required to review all fatal cases of police deadly force. ${ }^{48}$ In accordance with that policy, evidence could be and was received from the defense attorneys representing Officers Loehmann and Garmback. ${ }^{49}$ Ultimately, no criminal charges were recommended by the grand jury. ${ }^{50}$

Recent analysis indicates that thousands of fatal police shootings occurred between 2005 and 2015. ${ }^{51}$ The Brown and Rice cases have certainly intensified the national interest in police shootings, and significant national attention has been paid to the practice of prosecutors providing

\footnotetext{
${ }^{43}$ See Levine, supra, at 766.

${ }^{44}$ See St. Louis Public Radio, http://apps.stlpublicradio.org/ferguson-project/evidence.html, March 4, 2015 and updated December 2015.

${ }^{45}$ See S. David Mitchell, Ferguson: Footnote or Transformative Event? 80 Mo. L. Rev. 943, 950-951 (2015).

${ }^{46}$ See Cuyahoga County Prosecutor's Report on the November 22, 2014 Shooting Death of Tamir Rice, 5-7; see also Eric Sandy, Vince Grzegorek, and Sam Allard, The Grand Jury in the Tamir Rice Case Did Not Take a Vote on Charges, https://www.clevescene.com/scene-and-heard/archives/2016/01/20/the-grand-jury-in-thetamir-rice-case-did-not-take-a-vote-on-charges, January 20, 2016.

${ }^{47}$ See Cuyahoga County Prosecutor's Report, supra, at 31-33.

48 Id., at 34.

${ }^{49}$ Id. See also Ari Melber, The Tamir Rice Case Shows How Prosecutors Twist Grand Juries to Protect Police, https://www.washingtonpost.com/posteverything/wp/2015/12/29/in-tamir-rices-case-the-grand-juryprocess-was-turned-upside-down/?utm_term=.6a4475fa56fa, December 29, 2015; see also Robert Higgs, Tamir Rice Grand Jury Process Turns Secrecy Precedent on Its Head, but Experts Say That Could Pay Dividends, http://www.cleveland.com/metro/index.ssf/2015/12/tamir_rice_grand_jury_process_turns_secrecy_prece dent_on_its_head_but_experts_say_that_could_pay_dividends.html, December 11, 2015 and updated December 14, 2015.

${ }^{50}$ Id. (Melber); Id. (Higgs).

${ }^{51}$ See Kami Chavis Simmons, Increasing Police Accountability: Restoring Trust and Legitimacy Through the Appointment of Independent Prosecutors, 49 Wash. U. J. L. and Policy 137, 146 (2015); see also Kimberly Kindy and Kimbriell Kelly, Thousands Dead, Few Prosecuted, Washington Post, April 11, 2015, http://www.washingtonpost.com/sf/investigative/2015/04/11/thousands-dead-few-prosecuted/ (relying upon the research of Philip M. Stinson, Bowling Green State University criminologist, and information obtained from news reports, grand jury announcements, and new releases from prosecutors).
} 
full grand jury reviews in police officer cases. ${ }^{52}$ Given that fatal police shootings will not cease to occur and that in a majority of states many prosecutors who are elected to office will continue to have discretion as to whether to provide full grand jury reviews exclusively in police officer cases, the constitutional and ethical issues related to the provision of full grand jury reviews exclusively in police officer cases are highly relevant. Moreover, those issues are particularly important when one considers what appears to be a diminishing public faith in the criminal justice system and particularly in the use of grand juries to decide whether criminal charges are warranted in police officer cases. ${ }^{53}$

\section{Opening The Door}

Since its decision in United States v. Williams, The Court has not issued a decision concerning the constitutionality of providing full grand jury reviews exclusively to police officers. ${ }^{54}$ For that reason, to examine the legal and ethical implications of providing full grand jury reviews exclusively in police officer cases, an effort has been undertaken within this article to extrapolate from existing case decisions.

As noted previously, as a matter of interpreting its supervisory role in federal court proceedings, The Court in United States $v$. Williams declined to impose a constitutional requirement for federal prosecutors to disclose exculpatory evidence in grand jury proceedings. ${ }^{55}$ The Court, through Justice Scalia, declared that it would not impose such a requirement because to do so would alter the traditional role of the grand jury, transforming (emphasis added) it from an accusatory body into an adjudicatory body. ${ }^{56}$

However, at this juncture, it is important to take stock of what The Court did not address in United States $v$. Williams. Of greatest importance is the fact that The Court did not address the constitutional implications for prosecutors who themselves transform the traditional grand jury proceeding into a more expanded, arguably more adjudicative "mini-trial" by electing to provide full grand jury reviews in police officer cases. ${ }^{57}$ As previously noted, The Court in deciding that

\footnotetext{
52 See Melber, supra; see also Higgs, supra; see also St. Louis Public Radio, supra.

${ }^{53}$ See Restoring Legitimacy: The Grand Jury as the Prosecutor's Administrative Agency, 130 Harv. L. Rev. 1205, 1206 (2017); see also Walter Katz, Enhancing Accountability and Trust With Independent Investigations of Police Lethal Force, 128 Harv. L. Rev. F. 235 (2014-2015); see also Kristen Henning, Status, Race and the Rule of Law in the Grand Jury, 58 Howard L. J. 833 (2014-2015).

54 The effect of limited financial resources, case dismissals on alternative grounds, favorable plea bargains, acquittals at trial, and/or the absence of significant exculpatory evidence in some earlier cases may account to a fair extent for the absence of a decision by The Court to date. However, given the recent strong national interest in police shooting cases and the public's declining faith in the fairness of the criminal justice system, the absence of a decision to date does not serve to diminish the importance of the constitutional issues surrounding the provision of full grand jury reviews in police officer cases. Moreover, the potential for a future case certainly exists, especially in light of the recent Brown and Rice cases and the national scrutiny they have received.

55 See United States v. Williams, 504 U.S. 45 (1992).

${ }^{56} / d$., at 51-53.

${ }^{57}$ Id., at 38-39. (In United States v. Williams, the defendant as a private citizen contended that the prosecution failed to present substantial exculpatory evidence to the grand jury and that the indictment against him was legally flawed for that reason. Based upon its review of the traditional role of grand juries, The Court declined to provide any relief to the defendant.)
} 
prosecutors have no constitutional obligation to present exculpatory evidence to grand juries clearly rested its decision upon a review of the traditional role of grand juries as accusatory bodies. The Court's analysis and ultimate decision were not based upon a review of an expanded role of grand juries created by prosecutors, such as occurred in the Brown and Rice cases. ${ }^{58}$ In particular, The Court was not called upon to review Due Process or Equal Protection claims related to the differential treatment of police officers and private citizens based upon prosecutors electing to provide full grand jury reviews exclusively to police officers. Consequently, The Court's decision in United States $v$. Williams may very well have failed to provide prosecutors with a viable legal defense to the Due Process claims, Equal Protection claims, and ethical claims raised by people who have been denied full grand jury reviews in private citizen cases when, within the same jurisdiction, full grand jury reviews have been provided in police officer cases.

Issues related to fairness in private citizen cases can be resolved through the creation of a specific rule of procedure, statute, or constitutional provision that requires prosecutors to disclose exculpatory evidence to grand juries regardless of the identity or occupation of the defendant. As noted previously, some states have already created the procedural apparatus for doing just that in state grand jury proceedings. ${ }^{59}$ However, in the absence of a specific rule of procedure, constitutional provision, or statute, prosecutors may nevertheless encounter an obligation to provide a full grand jury review in private citizen cases when they "open the door" by electing to transform their grand jury proceedings from a traditional role to a more expanded role through the use of full grand jury reviews in police officer cases, as was done in the aforementioned Brown and Rice cases. Essentially, by creating an expanded role for their grand juries in police officer cases, prosecutors might create a constitutional obligation to provide full grand jury reviews in private citizen cases when none previously existed.

The foundation for this proposition can be found in two important cases addressed by The Court. In Griffin v. Illinois, ${ }^{60}$ when addressing the right of access to the courts, The Court was called upon to review the constitutionality of an Illinois statute that furnished for purposes of appeal free stenographic trial transcripts only to defendants convicted and sentenced to death. In all other criminal cases, the defendants on appeal were required to pay for the creation of trial transcripts. ${ }^{61}$ Utilizing a Due Process and Equal Protection analysis, The Court determined the statute to be unconstitutional. $^{62}$

In the relevant part, The Court in Griffin v. Illinois stated the following:

It is true that a State is not required by the Federal Constitution to provide appellate courts or a right to appellate review at all. ... But that is not to say that a State that does grant appellate review can do so in a way that discriminates against some convicted defendants on account of their poverty. ${ }^{63}$

58 Id., at 47-53.

${ }^{59}$ See State v. Hogan, 144 N.J. 232-234; see also Lombardo, supra, at 842-857; see also, Cassidy, supra, at 384-392.

${ }^{60}$ See Griffin et al. v. Illinois, 351 U.S. 12 (1956).

$61 / d$., at 14.

$62 / d$., at 20.

$63 / d$., at 18 . 
The decision in Griffin v. Illinois has been interpreted in support of the proposition that a state may not be required to offer an appellate system, but once a state elects to do so, the state cannot unfairly discriminate against people as part of providing that system to its citizens. ${ }^{64}$

In Evitts v. Lucey, ${ }^{65}$ The Court 29 years later faced a similar review of the system of appeals in Kentucky. The defendant claimed that he had been denied his right to counsel as part of his appeal from a criminal conviction. The government argued, inter alia, that because the state of Kentucky was not constitutionally required to create a system of appeals, the state's system of appeals was immune from constitutional scrutiny. ${ }^{66}$ Following the same reasoning employed in Griffin v. Illinois, The Court in Evitts v. Lucey declared that although a state may not be constitutionally required to create a system of appeals, once the state exercises its discretion (emphasis added) to create such a system, the state as a matter fundamental fairness under the Due Process clause must implement measures to ensure that defendants are treated fairly by being provided the effective assistance of counsel on appeal. ${ }^{67}$ Therefore, The Court's decisions in these cases clearly points out an important constitutional principle: Once a state in the exercise of its discretion elects to act in a particular area of the criminal justice system, Due Process and Equal Protection principles can be applied to create constitutional obligations where none previously existed.

Relevant to the issues raised within this article, it is true that prosecutors are not the "state" as that term was used within Griffin v. Illinois and Evitts v. Lucey in that prosecutors do not enact statewide legal systems such as those addressed in those cases. However, state prosecutors who take legal action on behalf of the state certainly qualify as "state actors" for purposes of Due Process and Equal Protection analysis. ${ }^{68}$ Consequently, prosecutors fully represent the interests of the states and qualify as state actors subject to Due Process and Equal Protection requirements when they pursue prosecutions through state-authorized grand jury proceedings. Therefore, as state actors, prosecutors have an obligation to seek fairness and justice in all criminal proceedings in which they participate, including grand jury proceedings. ${ }^{69}$

In summary, although The Court in Griffin v. Illinois and Evitts v. Lucey did not specifically address grand jury proceedings, the decisions in those cases lend considerable support to the proposition that prosecutors, as state actors, potentially create the legal obligation to provide full grand jury reviews in private citizen cases even though no such obligation previously existed. Like the state of Illinois in Griffin v. Illinois and the state of Kentucky in Evitts v. Lucey, prosecutors who are not constitutionally required to do so, but who nevertheless exercise their discretion to provide full grand jury reviews in police officer cases, are in effect creating a local grand jury system that will be subject to Due Process and Equal Protection requirements. The prosecutors may very well thereafter under Due Process and Equal Protection analysis be required to provide full grand jury reviews in private citizen cases as well.

${ }^{64}$ See Ronald D. Rotunda and John E. Nowak, Treatise on Constitutional Law: Substance and Procedure, 405 (West, Vol. 3, Fifth Edition, 2012); see also Johnson v. Bredesen, 624 F.3d 742, 760 (6th Cir. 2010) (Dissent by Circuit Judge Moore).

${ }^{65}$ See Evitts v. Lucey, 469 U.S. 387 (1985).

66 Id., at 400 .

67 Id., at 400-401.

68 See William J. Rich, Modern Constitutional Law, 127 (West, Vol. 1, Third Edition, 2011).

${ }^{69}$ See Berger v. United States, 295 U.S. 78 (1935). 


\section{The Arguments for Full Grand Jury Reviews in Police Officer and Private Citizen Cases}

\section{A. Application of Due Process and Equal Protection to Grand Jury Generally}

For those private citizens who are denied full grand jury reviews in jurisdictions that provide such reviews to police officers, several Procedural Due Process and Equal Protection principles can be relied upon as the foundation for challenges to the decisions to prosecute them.

First, the Due Process clause has been interpreted by The Court as a flexible legal protection that permits the creation of procedural protections depending upon the demands of a particular situation. ${ }^{70}$ Therefore, Due Process protections are not rigidly defined and limited to the specific constitutional guarantees set forth within the Bill of Rights. ${ }^{71}$ For example, even though the Sixth Amendment right to a speedy trial applies to unconstitutional delay during the post-indictment process, The Court determined long ago that Due Process protections apply to pre-arrest and preindictment delay by prosecutors in initiating criminal prosecutions. ${ }^{72}$ To be sure, the use of grand juries is an important facet of the pre-arrest and pre-indictment process, and Due Process protections therefore could arguably apply to the presentation of evidence during grand jury proceedings as an important aspect of the pre-indictment process.

Second, Procedural Due Process protections are designed to ensure that the government employs a fair decision-making process before taking any action that will directly impair the life or liberty of a person. ${ }^{73}$ The decision-making process must be fundamentally fair when it is being determined whether there is a factual or legal basis for the government's decision to take such action against a defendant. ${ }^{74}$ At the same time, Equal Protection guarantees require the government to treat similarly situated defendants in the same manner. ${ }^{75}$ Any arbitrary preference for one class of persons over another may give rise to a claim of a denial of equal protection under the laws. ${ }^{76}$

Under Procedural Due Process analysis, the grand jury process is certainly a key aspect of the decision-making process related to who will or will not be prosecuted for criminal charges. When a grand jury has made a decision to prosecute and a prosecution is undertaken, the subsequent arrest of the defendant and imposition of bail place significant restrictions upon the defendant's liberty and freedom of movement, especially if the conditions of bail serve to confine his or her

\footnotetext{
70 See Gilbert v. Homar, 520 U.S. 924, 930 (1997).

71 See Rich, supra, at 165 (West, Vol. 2, Third Edition, 2011).

72 See United States v. Lovasco, 431 U.S. 783 (1977); see also United States v. Marion, 404 U.S. 307 (1971); see also Rich, supra, at 165 (citing United States v. Marion, 404 U.S. 307 (1971) (West, Vol. 2, Third Edition, 2011). (The Court has declared that although the Sixth Amendment Right to Speedy Trial applies only to the lapse of time between the issuance of an indictment and the ultimate trial, the application of the Due Process principle of fundamental fairness may result in the dismissal of a prosecution for those defendants who have experienced unreasonable and prejudicial delay by police and/or prosecutors before a criminal prosecution is initiated.)

73 See Ronald D. Rotunda and John E. Nowak, Treatise on Constitutional Law: Substance and Procedure, 722 (West, Vol. 2, Fifth Edition, 2012).

${ }^{74}$ See Ronald D. Rotunda and John E. Nowak, Treatise on Constitutional Law: Substance and Procedure, 143144 (West, Vol. 1, Fifth Edition, 2012).

75 See Rotunda and Nowak, supra, at 785 (West, Vol. 2, Fifth Edition, 2012).

${ }^{76}$ See Nordlinger v. Hahn, 505 U.S. 1, 11 (1992); see also Rotunda and Nowak, supra, at 21 (West, Vol. 3, Fifth Edition, 2012).
} 
movement to a particular jurisdiction-and more so when bail cannot be posted and the person remains incarcerated during the pendency of the court proceedings. Therefore, the application of Procedural Due Process requirements for a fundamentally fair presentation of evidence to grand juries as part of the decision-making process is certainly reasonable. Moreover, as will be argued in greater detail later, Equal Protection principles can protect against any arbitrary distinctions between police officers and private citizens in terms of the nature and quality of the grand jury proceedings they will receive.

Third, the application of Due Process and Equal Protection principles to the grand jury process is nothing new. Specifically, racial discrimination during the selection of grand jurors has been area in which Due Process and Equal Protection claims have been successful. ${ }^{77}$ Although The Court has understandably considered issues related to racial discrimination to be of major importance, the grand jury selection cases demonstrate that grand jury proceedings are well within the scope and application of Due Process and Equal Protection protections.

Fourth and finally, over the years the courts have also been called upon to scrutinize the misconduct of prosecutors when they are presenting evidence during the course of grand jury proceedings, and the courts have done so with reference to the need for prosecutors to abide by the principle of fundamental fairness when conducting grand jury proceedings. ${ }^{78}$ The Court has also recognized the importance of a person's reputation in the community. When court proceedings may result in damage to a person's reputation, Due Process protections have been applied to ensure a fair opportunity to be heard. ${ }^{79}$ As the United States Court of Appeals for the Third Circuit stated in United States v. Serubo, ${ }^{80}$ :

... the prosecutor operates without the check of a judge or trained legal adversary, and virtually immune from public scrutiny. The prosecutor's abuse of his special relationship to the grand jury poses an enormous risk to defendants as well. For while in theory a trial provides the defendant with a full opportunity to contest and disprove the charges against him, in practice, the handing up of an indictment will often have a devastating personal and professional impact that a later dismissal or acquittal can never undo. Where the potential for abuse is so great, and the consequences of a mistaken indictment so serious, the ethical

\footnotetext{
77 See Rich, supra, at 204, 213-14 (West, Vol. 2, Third Edition, 2011). See also Campbell v. Louisiana, 523 U.S. 392 (1998). (Campbell was indicted on a charge of murder. In a pretrial motion to quash the indictment, Campbell alleged that the grand jury was selected in a racially discriminatory manner that violated, inter alia, his equal protection and due process rights under the Fourteenth Amendment. The Court determined that Campbell had the requisite standing to raise his constitutional claims. In doing so, The Court declared that Equal Protection and Due Process objections to discrimination against black persons may be raised with respect to the selection of grand jurors who ultimately serve on the grand jury.) See also Peters v. Kiff, 407 U.S. 493 (1972). (Peters was indicted for burglary by a grand jury in the state of Georgia. The Court declared that Due Process protections are applicable when racial discrimination occurs during the selection of grand jurors.)

78 See Dissent of Justice Stevens, United States v. Williams, 504 U.S. 36, 60-64 (1992). (Examples of prosecutorial misconduct during grand jury proceedings that have been reviewed by the courts include failing to inform the grand jury of its authority to subpoena witnesses, misstating the facts on cross-examination of a witness, operating under a conflict of interest, and presenting perjured testimony.)

${ }^{79}$ See Rich, supra, at 61 (West, Vol. 2, Third Edition, 2011).

${ }^{80}$ See United States v. Serubo, 604 F.2d 807 (3rd Cir. 1979).
} 
responsibilities of the prosecutor, and the obligation of the judiciary to protect against even the appearance of unfairness, are correspondingly heightened. ${ }^{81}$ (parenthetical emphasis added)

Furthermore, The Court in United States v. Williams did not necessarily foreclose court scrutiny of prosecutorial conduct in grand jury proceedings. ${ }^{82}$ Consequently, Due Process and Equal Protection principles have been applied and will continue to be applied to the grand jury process. The Court in particular has scrutinized the presentation of evidence during grand jury proceedings and has not foreclosed the review of claims related to fundamental procedural fairness and the creation of arbitrary distinctions. Claims of that nature, when raised by private citizens who have been denied full grand jury reviews that have been provided exclusively to police officers, may very well give rise to scrutiny by the courts. To be sure, the exercise of scrutiny by the courts is of significant consequence because any private citizen who successfully raises Due Process and/or Equal Protection claims with regard to the grand jury process may ultimately receive a dismissal of the indictment or a reversal of the judgment of conviction. ${ }^{83}$

\section{B. Application of Due Process and Equal Protection to Police Officer and Private Citizen Cases}

As previously noted, like the state of Illinois in Griffin v. Illinois ${ }^{84}$ and the state of Kentucky in Evitts $v$. Lucey, ${ }^{85}$ prosecutors who are not constitutionally required to do so but who nevertheless exercise their discretion to provide full grand jury reviews in police officer cases, in effect, create a local grand jury system that will be subject to the Due Process and Equal Protection requirements. The prosecutors may very well thereafter under Due Process and Equal Protection analysis be required to provide full grand jury reviews in private citizen cases as well.

The grand jury selection cases $^{86}$ and prosecutorial misconduct ${ }^{87}$ cases also indicate that Equal Protection and Due Process principles can be and have been applied to grand jury proceedings. Additionally, as an important facet of the grand jury process, the Due Process principles requiring fair decision making by government officials when a person's life or liberty is at stake ${ }^{88}$ arguably apply to the decision-making process of prosecutors, including the decision to provide full grand jury reviews in police officer cases. Specifically, as part of the prosecutor's decision-making

${ }^{81}$ Id., at 817; for similar remarks, see also Dissent of Justice Stevens, United States v. Williams, 504 U.S. $62-$ 63 (1992).

82 See Wayne R. LaFave, Jerold H. Israel, Nancy J. King, and Orin S. Kerr, Criminal Procedure (West's Criminal Practice Series), 670-671 (West, Vol. 4, Fourth Edition, 2015).

83 See Peters v. Kiff, 407 U.S. 505; see also Campbell v. Louisiana, 523 U.S. 395; see also Rich supra, at 164, 204, 213-214 (West, Vol.2, Third Edition, 2011).

${ }^{84}$ See Griffin v. Illinois, 351 U.S. 12 (1956).

${ }^{85}$ See Evitts v. Lucey, 469 U.S. 387 (1985).

86 See Campbell v. Louisiana, 523 U.S. 392 (1998); see also Peters v. Kiff, 407 U.S. 493 (1972).

${ }^{87}$ See Dissent of Justice Stevens, United States v. Williams, 504 U.S. 60-64 (1992). (Examples of prosecutorial misconduct during grand jury proceedings that have been reviewed by the courts include failing to inform the grand jury of its authority to subpoena witnesses, misstating the facts on cross-examination of a witness, operating under a conflict of interest, and presenting perjured testimony.)

${ }^{88}$ See Rotunda and Nowak, supra, at 722, 785 (West, Vol. 2, Fifth Edition, 2012); see also Rotunda and Nowak, supra, at 143-144 (West, Vol. 1, Fifth Edition, 2012); see also Nordlinger v. Hahn, 505 U.S. 11; see also Rotunda and Nowak, supra, at 21 (West, Vol. 3, Fifth Edition, 2012). 
process, in those jurisdictions where grand jury proceedings will be used to address both police officer cases and private citizen cases, any differential treatment of police officers in the form of providing full grand jury reviews in police officer cases and only traditional grand jury reviews in private citizen cases will most certainly give rise to a strong perception of prosecution bias in favor of police officers and against private citizens, which will cast serious doubt upon the constitutional integrity of the grand jury process. ${ }^{89}$ By the same token, where grand jury proceedings are optional, any decision to provide a full grand jury review in police officer cases and to deny any form of grand jury review in private citizen cases will give rise to the same strong perception of prosecution bias. In essence, any such differential treatment may very well be viewed by the courts as reflecting the same measure of arbitrariness, unfairness, and inequality that was addressed by The Court in Griffin v. Illinois, ${ }^{90}$ Evitts v. Lucey, ${ }^{91}$ the grand jury discrimination cases, ${ }^{92}$ and the prosecutorial misconduct cases. ${ }^{93}$

Charging policies exist to guide prosecutors through the process of making decisions as to whether an individual will be charged, and if so with which offense(s). Any internal operating policy created by prosecutors that provides for the use of full grand jury reviews to determine whether a police officer will be charged, and if so with which offense(s), qualifies as a charging policy. Under the Equal Protection clause, prosecutors do not have unlimited latitude in developing charging policies. Charging policies must be carefully developed and must comport with constitutional protections against unlawful discrimination in charging decisions. ${ }^{94}$ Any charging policy or criminal procedure must be applied with equal force for the benefit of all similarly situated defendants. ${ }^{95}$ Although it is true that prosecution charging policies can expand upon Due Process protections to achieve procedural fairness, charging policies cannot serve to promote discriminatory prosecution practices. ${ }^{96}$ By way of example, as previously noted, The Court has determined that prosecutors are not constitutionally required to present exculpatory evidence to grand juries. Nevertheless, the Department of Justice has instituted an internal operating policy that expands procedural protections and provides for the presentation to grand juries of "substantial evidence that directly negates the guilt of the subject of the investigation." 97 Of particular importance, however, is the

\footnotetext{
${ }^{89}$ See Peters v. Kiff, supra, 407 U.S. 502-503. ("Illegal and unconstitutional jury selection procedures cast doubt on the integrity of the whole judicial process. They create the appearance of bias in the decision of individual cases and they increase the risk of actual bias as well.) See also Brenner and Shaw, supra, at 169 (Thomson-West, Vol. 1, Second Edition, 2006).

${ }^{90}$ See Griffin v. Illinois, 351 U.S. 12 (1956).

${ }^{91}$ See Evitts v. Lucey, 469 U.S. 387 (1985).

92 See Campbell v. Louisiana, 523 U.S. 392 (1998); see also Peters v. Kiff, 407 U.S. 493 (1972).

${ }^{93}$ See Dissent of Justice Stevens, United States v. Williams, 504 U.S. 60-64 (1992). (Examples of prosecutorial misconduct during grand jury proceedings that have been reviewed by the courts include failing to inform the grand jury of its authority to subpoena witnesses, misstating the facts on cross-examination of a witness, operating under a conflict of interest, and presenting perjured testimony.)

${ }^{94}$ See Fish, supra, at 284-286.

95 See Myers v. Ylst, 897 F.2d 417, 421 (9th Cir. 1990); see also Griffith v. Kentucky, 479 U.S. 314, 323, 107 S. Ct. 708, 713 (1987).

${ }^{96}$ See Fish, supra, at 295.

97 Id., at 294; see also United States Attorney's Manual section 9-11.233 (2015). (The manual provides that prosecutors must present or otherwise disclose to the grand jury substantial evidence that directly negates the guilt of a subject of an investigation before seeking an indictment against that person.)
} 
fact that the Department of Justice policy does not benefit only one particular category of defendants, such as police officers, but instead applies to all grand jury cases regardless of the identity or occupation of the defendant. Consequently, the Department of Justice policy does not reflect a discriminatory purpose or design.

Prosecutors may argue that police officer cases often involve a complex set of facts and legal issues, and for that reason, exculpatory evidence, if it exists, should be brought to the attention of the grand jury. Consequently, prosecutors may very well argue that full grand jury reviews are essential to the process of deciding whether a criminal prosecution is warranted in police officer cases and yet are unnecessary in private citizen cases. In essence, prosecutors may argue that the defendants in police officer cases and private citizens are not similarly situated for purposes of Equal Protection analysis or Due Process fundamental fairness analysis because police officer cases are more complicated than private citizen cases.

Although it is true that prosecutors may legitimately argue full grand jury reviews should be used in police officer cases, those same prosecutors must understand that as a matter of Equal Protection principles, it may very well be successfully argued that private citizens in private citizen cases are situated similarly to police officers in police officer cases. Both lawyers and judges well know that private citizen cases often entail complex facts and complex legal self-protection issues with which jurors must grapple. In addition, common sense informs us that exculpatory evidence can also exist in private citizen cases. Moreover, both police officer cases and private citizen cases entail the potential misuse of deadly force that has resulted in the death of an individual, and both entail claims by the actor that the use of deadly force was reasonable and necessary under the circumstances of the case. Like police officers, many private citizens will have exculpatory versions to present to a grand jury in support of their claim that the use of force was justified under the circumstances.

Although it is also true that police officers encounter different circumstances related to the performance of their professional duties, those circumstances can be effectively addressed as part of a full grand jury review (i.e., through the presentation of expert testimony, as was done in the Tamir Rice case), just as can be any special circumstances that private citizens face in private citizen cases. The professional roles and duties of police officers do not justify a difference in prosecutors' treatment of police officer cases and private citizen cases.

Grand jury procedures that differ based upon who is the potential defendant are subject to claims of arbitrariness and undermine the essential need for the perception of legitimacy in the criminal justice process. ${ }^{98}$ Furthermore, as noted previously, The Court has determined that Due Process is denied when the procedural circumstances create the likelihood or appearance of bias. ${ }^{99}$

The risk of actual prejudice or harm to defendants in private citizen cases also exists if the defendants are denied the opportunity for full grand jury reviews. Evidence exists that private citizens experience exceptionally high indictment rates when prosecutors utilize traditional grand juries with no opportunity for the defense to submit exculpatory evidence or at least evidence favorable to the private citizen. ${ }^{100}$ It is highly doubtful that police officers who receive full grand jury reviews will experience such high rates of indictment, and it is further doubtful that private

\footnotetext{
98 See 130 Harv. L. Rev., supra, at 1219.

${ }^{99}$ See Peters v. Kiff, 407 U.S. 502.

100 See Siegel and Worral, supra, at 187; see also Neely, supra, at 182; see also Ric Simmons, Re-examining the Grand Jury: Is There Room for Democracy in the Criminal Justice System? 82 B.U. L. Rev. 1, 31-35 (2002).
} 
citizens who receive full grand jury reviews will experience such high indictment rates. Time and well-structured research will tell. However, in the meantime, a significant potential for actual prejudice or harm in the form of higher indictment rates will exist and will provide private citizens who are denied full grand jury reviews with the foundation for legitimate claims of the denial of Due Process and Equal Protection. Corresponding to the potential experience of higher indictment rates for private citizens, one cannot reasonably discount the personal implications of being under indictment. The issuance of an indictment can have substantial negative consequences for a defendant, including but not limited to loss of employment, loss of liberty pending trial or dismissal, disruption of family, loss of reputation within the community, and heavy financial costs, none of which is certain to be restored if a dismissal or acquittal occurs at some later date. ${ }^{101}$

When court proceedings may result in damage to a person's reputation, Due Process protections have been applied to ensure a fair opportunity to be heard. ${ }^{102}$ That having been said, a critical question arises: Why should private citizens in private citizen cases be forced to endure a prosecution and await a trial before an opportunity to present exculpatory evidence arises when police officers can have exculpatory evidence presented to a grand jury and succeed in avoiding the negative ramifications of a prosecution altogether? It would be fundamentally unfair to advise suspects in private citizen cases that their opportunity to present favorable or exculpatory evidence will occur at the time of trial while at the same time police officers are advised that they will have the opportunity to present favorable or exculpatory evidence in full grand jury reviews to potentially avoid any prosecution whatsoever. In view of the substantial negative consequences to private citizens a prosecution can bring, it is difficult to argue that police officers should be afforded special treatment through full grand jury reviews because they personally stand to lose significantly more than private citizens if prosecuted. A decision to allow full grand jury reviews exclusively in police officer cases unfairly provides a clear and substantial benefit to police officers that private citizens do not enjoy and, as such, seriously offends both Due Process fundamental fairness and Equal Protection arbitrary discrimination principles.

One distinct reality is that prosecutors may create a policy to provide full grand jury reviews to police officers on the basis of political concerns. ${ }^{103}$ In 45 states, the top prosecutors at a local level are elected as district attorneys or county prosecutors. ${ }^{104}$ Most people, especially police officers, would be grateful for the opportunity to provide their version of events to a grand jury, to provide expert reports that support their version of events, and to present the testimony of lay witnesses who support their version of events. The opportunity to do so is even more desirable when police officers know the prosecutor will be the one producing and presenting that information on their behalf and the officers may in the end escape a criminal prosecution.

At the same time, full grand jury reviews may very well allow a prosecutor to avoid the negative consequences of a decision to charge a police officer by permitting the prosecutor to assign responsibility for his or her decision to the grand jurors. Finally, the prosecutor may use full

\footnotetext{
${ }^{101}$ See Dissent of Justice Stevens in United States v. Williams, 504 U.S. 62-63 (1992); see also Neely, supra, at 188.

102 See Rich, supra, at 61 (West, Vol. 2, Third Edition, 2011).

103 See Ben Trachtenberg, No, You 'Stand Up': Why Prosecutors Should Stop Hiding Behind Grand Juries, 80 Mo. L. Rev. 1099,1100-1101 (2015).

104 See Fish, supra, at 280; see also Reconsidering the Use of the Grand Jury: Eliminating Prosecutorial Discretion to Indict Law Enforcement Officers, 38 T. Jefferson L. Rev. 202, 209 (2016).
} 
grand jury reviews to avoid the negative political consequences registered by members of the community because of a decision not to charge. Once again, the prosecutor would be in a position to assign responsibility for the decision to the grand jurors.

The achievement of any political goal by providing full grand jury reviews to police officers is unrealistic for practical and constitutional reasons. First and foremost, political concerns and objectives will not withstand a constitutional challenge raised by private citizens. Although the use of full grand jury reviews may be politically expedient for prosecutors, political expedience has not served and cannot serve as the justification for disparate treatment under an Equal Protection or Due Process analysis.

Secondly, prosecutors by the very nature of grand jury proceedings control the presentation of evidence to grand jurors. Prosecutors determine which questions will be asked of witnesses and which ones will not be asked. Prosecutors also determine which evidence will be presented and which evidence will be withheld from consideration by the grand jurors. ${ }^{105}$ Thus, prosecutors can certainly maintain a significant degree of control over the ultimate outcome of the grand jury proceedings. Given the nationwide attention to cases such as those of Rice and Brown, the public, if not previously aware, is now much more aware of the degree of control that prosecutors exercise over the grand jury process. As a purely practical matter, therefore, prosecutors cannot effectively shield themselves from a grand jury's decision not to indict a police officer by claiming that the grand jury's decision was the product of its independent judgment and deliberation.

There is one final legal point to be advanced. Up to this point, the legal implications of providing full grand jury reviews in police officer cases and only traditional grand jury reviews in private citizen cases have been addressed. To be sure, though, when prosecutors elect not to use grand jury proceedings at all in private citizen cases, the private citizens who are denied the benefits of a full grand jury review that is being provided to police officers within the same jurisdiction will experience a denial of fundamental fairness and equal protection of the laws comparable to that experienced by private citizens who receive traditional grand jury reviews while police officers in the same jurisdiction receive full grand jury reviews. Essentially, the foregoing concerns for arbitrariness, fundamental fairness, and equal protection of the laws will not disappear if and when prosecutors make charging decisions in private citizen cases without the use of grand juries.

\section{Ethical Consideration in Grand Jury Proceedings}

In addition to constitutional concerns, legitimate ethical concerns arise when full grand jury reviews are provided in police officer cases but not in private citizen cases. It has long been understood that prosecutors have an ethical obligation to seek justice in criminal cases, not merely to seek convictions. ${ }^{106}$ Although they do not have the force and effect of law, the American Bar Association ("ABA") and the National District Attorneys Association ("NDAA") have created specific ethical standards related to the conduct of prosecutors during grand jury proceedings.

The ABA has issued the following relevant standard:

105 See 130 Harv. L. Rev., supra, at 1208.

106 See Ellen J. Bennett, Elizabeth J. Cohen, and Martin Wittaker, Annotated Model Rules of Professional Conduct, 384 (The Center for Professional Responsibility, American Bar Association, Seventh Edition, 2011); see also Ronald D. Rotunda and John S. Dzienkowski, Legal Ethics: The Lawyer's Deskbook on Professional Responsibility, 886 (The Center for Professional Responsibility, American Bar Association, 2014-2015 ed.). 
No prosecutor should knowingly fail to disclose to the grand jury evidence which tends to negate guilt or mitigate the offense. ${ }^{107}$

The NDAA in similar fashion has promulgated the following standard:

A prosecutor should disclose any credible evidence of actual innocence known to the prosecutor or other credible evidence that tends to negate guilt, as required by law or applicable rules of ethical conduct. ${ }^{108}$

Again, consistent with the foregoing standards, the Department of Justice has created an internal operating policy regarding the disclosure of exculpatory evidence. Under that nonbinding policy, prosecutors are required to disclose substantial exculpatory evidence known to them if that evidence negates the guilt of the subject of the investigation. ${ }^{109}$ The Department of Justice created and implemented the policy based upon the belief that the Department would be in the best position to seek justice by requiring prosecutors to disclose substantial exculpatory evidence as provided under the policy regardless of the identity or occupation of the subject of the investigation. ${ }^{110}$

Adhering to these ethical standards in grand jury proceeding for police officer cases is certainly laudable. However, there is no legitimate basis for failing to adhere to those same standards when prosecutors are addressing private citizen cases. The use of traditional grand juries or no grand juries at all in private citizen cases while full grand jury reviews are provided in police officer cases cannot begin to comport with the responsibility of prosecutors to seek justice in all cases.

\section{Additional Issues: Full Grand Jury Reviews in All Cases and the Use of Independent Prosecutors}

\section{A. Full Grand Jury Review in All Cases}

The purpose of this article has been to undertake a constitutional analysis of the exercise of prosecutorial discretion to provide full grand jury reviews exclusively to police officers in police officer cases. Although viable constitutional arguments exist for the obligation to provide full grand jury reviews in private citizen cases when such reviews are provided in police officer cases, a viable constitutional argument for requiring the provision of full grand jury reviews in all criminal cases involving private citizens does not exist, and for that reason, it has not been advanced within this article.

First, in those jurisdictions where prosecutors have not elected to institute a policy or practice of providing full grand jury reviews in police officer cases, the decision in United States v. Williams has been viewed as settling the point. In other words, The Court has already decided that it will not require the presentation of exculpatory evidence to grand juries in all criminal cases, whether they involve police officers or private citizens as potential defendants.

107 See ABA Standard 3-3.6(b), Quality and Scope of Evidence Before Grand Jury (ABA Standards for Criminal Justice: Prosecution and Defense Function, Third Edition, 1993).

108 See NDAA Standard 3-3.5(a), Evidence Before the Grand Jury (National District Attorneys Association, National Prosecution Standards, Third Edition, 2009).

${ }^{109}$ See Neely, supra, at 173; see also Eaton, supra, at 498.

${ }^{110}$ See Eaton, supra, at 498-499. 
Second, as argued within this article, an exception to the general rule enunciated by The Court in United States $v$. Williams arguably exists in those jurisdictions where prosecutors have elected to institute a policy or practice of providing full grand jury reviews exclusively in police officer cases. The Court has yet to weigh in on that matter. Nevertheless, if asked to address whether full grand jury reviews should be provided in all cases involving private citizens, The Court will not likely determine that Due Process and Equal Protection principles support an argument that such reviews should be provided to all private citizens in all criminal cases (i.e., cases involving burglary, robbery, thefts, assaults). Essentially, the degree of unfairness and arbitrary discrimination normally addressed by those constitutional principles will not likely be deemed present when full grand jury reviews are denied in cases involving burglary or theft as opposed to cases involving the use of deadly force that has resulted in death and in which, like police officers, private citizens are claiming that the use of force was fully justified under the circumstances. The strongest arguments for fundamental unfairness under Due Process principles and arbitrary discrimination under Equal Protection principles are founded upon the proposition that police officers in police officer cases and private citizens in private citizen cases are similarly situated under the law, and for that reason, both deserve the benefit of full grand jury reviews. The same cannot be argued nearly as effectively when all other forms of criminal cases involving private citizens as potential defendants are addressed.

\section{B. Independent Prosecutors}

Based upon the proposition that prosecutors have an inherent conflict of interest when making charging decisions concerning police officers with whom they closely work, some have called for the use of independent prosecutors in police officer cases. ${ }^{111}$ The argument has been advanced that the use of independent prosecutors who have no relationship with the police officers or the department at issue will have the capacity to avoid the inherent conflicts of interest that local prosecutors face. ${ }^{112}$ Essentially, the independent prosecutors would be appointed by the government to investigate and decide whether a prosecution was warranted in particular police officer cases. ${ }^{113}$ The charging decision would thereby be wholly removed from the local prosecutors and placed in the hands of an independent prosecutor.

The use of independent prosecutors, however, will not eliminate the constitutional issues addressed within this article. As previously noted, indicting grand jury systems exist in 49 states, ${ }^{114}$ and only approximately one-third of those states require the presentation of exculpatory evidence to grand juries. ${ }^{115}$ Therefore, in a majority of states, prosecutors can exercise their discretion as to whether to provide full grand jury reviews. Unless the grand jury systems are wholly abolished and replaced by independent prosecutors in those states, local prosecutors will continue to avail

111 See Chavis Simmons, supra, at 150, 153-157.

112 Id., at 153.

113 See 38 T. Jefferson L. Rev., supra, at 214-217.

${ }^{114}$ See Neubauer and Fradella, supra, 279 (Cengage, 12th Edition, 2015).

115 See State v. Hogan, 144 N.J. 233; see also Lombardo, supra, at 842-857; see also Cassidy, supra, at 382392. (The states of Alaska, Arizona, California, Hawaii, Massachusetts, Minnesota, Montana, Nevada, New Jersey, North Dakota, Oregon, and Utah require the presentation of exculpatory evidence to grand juries. The same is required within the District of Columbia. New York, New Mexico, and Georgia provide an opportunity for the potential defendant to appear and present evidence.) 
themselves of the grand jury process and will have the opportunity to develop prosecution policies for the investigation and prosecution of police officer cases that could include the provision of full grand jury reviews only in police officer cases. To the extent that they do so, the constitutional and ethical issues raised within this article will exist.

It is also important to note that any states that do adopt the use of independent prosecutors will nevertheless be able to retain their grand jury systems. Ultimately then, like all other prosecutors, the independent prosecutors will have the authority to decide what evidence will be presented to grand juries in police officer cases. If independent prosecutors are used only for police officer cases and the prosecutors' policy is to provide full grand jury reviews in police officer cases, the use of independent prosecutors will not serve to eliminate the Due Process, Equal Protection, and ethical issues raised when full grand jury reviews are provided exclusively in police officer cases and not in private citizen cases.

Ultimately, a strong reform to be achieved would be for states with grand jury systems to require the presentation of exculpatory evidence in deadly force cases without reference to the identity or occupation of the defendant, and to use independent prosecutors to present the cases so as to minimize the concerns regarding an inherent conflict of interest.

\section{Conclusion}

Whether prosecutors resort to the use of a traditional grand jury process or use no grand jury process at all to review private citizen cases (as they are defined within this article), strong arguments exist that private citizens will, as a matter of constitutional analysis, be unjustifiably denied the benefits of a full grand jury review when such reviews are provided exclusively to police officers in police officer cases. That is not to say that prosecutors should decline to provide full grand jury reviews in police officer cases. However, it is to say that by offering such reviews in police officer cases, prosecutors may very well create for themselves both legal and ethical obligations to provide those same reviews in private citizen cases. The United States Supreme Court in United States $v$. Williams based its decision upon a review of the traditional role of grand juries, not upon the expanded role recently used by some prosecutors in which exculpatory evidence or at least evidence favorable to police officers was presented to grand juries. The constitutional ramifications of such a transformation of grand jury proceedings by prosecutors was not even remotely considered by The Court in United States $v$. Williams.

If prosecutors do not favor the idea of providing full grand jury reviews in private citizen cases because doing so would serve to convert the grand jury process into a "mini-trial," they have the option of declining to do so in police officer cases. It is not being advocated that on constitutional grounds, a general obligation to provide full grand jury reviews should be foisted upon prosecutors in all states and in all cases. However, it is being argued that prosecutors may very well foist upon themselves the obligation to provide full grand jury reviews in private citizen cases when, in their own exercise of professional discretion, they elect to create a special grand jury process within their jurisdictions by providing full grand jury reviews in police officer cases. In essence, in the absence of a relevant statute, regulation, or rule of procedure that requires them to do so, prosecutors may very well hold the legal keys as to whether they will be required to provide full grand jury reviews in private citizen cases. 
Declaration of Conflicting Interests

The author declares no potential conflicts of interest with respect to the research, authorship, and/or publication of this article.

Funding

The author received no financial support with respect to the research, authorship, and/or publication of this article.

\section{Author Biography}

Joseph P. Conti is an assistant professor in the Department of Criminal Justice, Anthropology, and Forensic Studies of Edinboro University in Edinboro, Pennsylvania. He is also an attorney who has been practicing both civil and criminal law in Pennsylvania since 1983 and is the former district attorney of Erie County, Pennsylvania. 